\title{
KINERJA GURU BIMBINGAN KONSELING DALAM PENYUSUNAN RENCANA PROGRAM LAYANAN MELALUI PENDAMPINGAN SUPERVISI KLINIS
}

\author{
Karsono \\ Pengawas SMP Dinas Pendidikan Kabupaten Klaten \\ drskarsonompd@gmail.com
}

\begin{abstract}
This research is motivated by the unoptimally performance of teachers in a planning service program has so far not optimal. The research objective is to improve the performance of teachers in the planning service program in region Delanggu Klaten Working Group by 30 teachers. Methods of data collection using observation, documentation, and assignment of teachers in planning services program Analysis of data using a critical and comparative analysis. Indicators of success using the criteria limit minimal is 80, and the class completeness 100\%. Research procedure uses cycles. From the results of research and discussion know that obtained summary data is the initial condition, Cycle I, II performance counseling teachers in planning services program, the initial conditions by an average of 75 and the first cycle an average of 80 and the second cycle by an average of 90 . from this data, it seems clear that an increase in the average value of the initial conditions to the first cycle of five digits $(6.7 \%)$, from the first cycle to the second cycle an increase of 10 digits $(12.5 \%)$, from pre cycle to the second cycle an increase of 15 digits (20\%). The highest value of the initial stages of the condition by 84 and 90 as well as the first cycle of the second cycle of 98 It is clear that from the stage of initial conditions for the first cycle occurred from the initial conditions to the first cycle of six digits (7.1\%), from the first cycle to the second cycle an increase of 8 digits (8.9\%), and from the initial conditions to the second cycle an increase of 14 digits (16.7\%). The lowest value obtained for the early stages of the condition of the first cycle of 67 and 72 and the second cycle of 87. thus, can be affirmed that the initial conditions of the stage to the first cycle an increase of 5 digits (7.5\%), from the first cycle to the second cycle an increase of 15 digits (22.4\%), and from the initial conditions to the second cycle an increase of 20 digits (29.9\%). Percentage of performance criteria counseling teachers in preparing plan preparation program obtained from the initial conditions of $28 \%$ and the first cycle was obtained by $68 \%$ and the second cycle at $100 \%$. It seems clear that the initial conditions of the stage to the first cycle an increase of $40 \%$, from the first cycle to the second cycle an increase of $32 \%$, and from the initial conditions to the second cycle an increase of $72 \%$. Thus, teachers performance in counseling services from the initial conditions to the second cycle brought a significant rise.
\end{abstract}

Keywords: teacher performance, counseling, program planning services 


\section{PENDAHULUAN}

Proses pembelajaran diawali dengan perencanaan, dilanjutkan dengan pelaksanaan, dan penilaian, bahkan dipandang perlu dilaksanakan pengayaan dan perbaikan. Bagian akhirnya adalah pengawasan. Hal itu ditegaskan oleh PP 19/2005, pasal 19, ayat (3), "Setiap satuan pendidikan melakukan perencanaan proses pembelajaran, pelaksanaan proses pembelajaran, penilaian hasil pembelajaran, dan pengawasan proses pembelajaran untuk terlaksananya proses pembelajaran yang efektif dan efisien" Perencanaan proses pembelajaran dilakukan oleh pengawas satuan pendidikan bersama dengan pendidik. Perencanaan itu berbentuk silabus dan rencana program layanan (RPL). Pada pasal 20, PP 19/2005 ditegaskan, "Perencanaan proses pembelajaran meliputi silabus dan rencana program layanan yang memuat sekurangkurangnya tujuan pembelajaran, materi ajar, metode pengajaran, sumber belajar, dan penilaian hasil belajar.

Sesuai dengan Permendiknas Nomor 41 Tahun 2007 tentang Standar Proses dijelaskan bahwa RPL dijabarkan dari silabus untuk mengarahkan kegiatan belajar peserta didik dalam upaya mencapai KD. Setiap guru pada satuan pendidikan berkewajiban menyusun RPL secara lengkap dan sistematis agar pembelajaran berlangsung secara aktif, kreatif, efektif dan menyenangkan, dan dapat menumbuhkan prakarsa, kreativitas, dan kemandirian sesuai dengan bakat, minat, perkembangan fisik dan psikologis peserta didik. RPL disusun dengan memperhatikan perbedaan jenis kelamin, kemampuan awal, tingkat intelektual, minat, motivasi belajar, bakat, potensi, kemampuan sosial, emosi, gaya belajar, kebutuhan khusus, kecepatan belajar, latar belakang budaya, watak/karakter, norma, nilai, dan/atau lingkungan peserta didik

RPL disusun dengan memperhatikan keterkaitan dan keterpaduan antara SK, KD, materi dan kegiatan pembelajaran, indikator pencapaian kompetensi, penilaian, dan sumber belajar dalam satu keutuhan pengalaman belajar. RPL disusun dengan mengakomodasikan pembelajaran tematik, keterpaduan lintas mata pelajaran, lintas aspek belajar, dan keragaman budaya. Penyusunan RPL oleh guru pada dasarnya dilakukan secara individu, meskipun tidak dilarang secara berkelompok. Jika RPL yang bermasalah berarti yang beratanggung jawab adalah pendidik. Jadi di dalam perencanaan proses pembelajaran sudah terlihat dikotomus (pemisah) tanggung jawab antara pengawas satuan pendidikan dengan guru.

Kemampuan menyusun RPL harus dimiliki oleh semua guru yang bertugas mengajar aik guru kelas maupun guru mata pelajaran, supaya kegiatan pembelajaran yang dilakukan berjalan optimal, maka guru tersebut harus mampu membuat perencanaan pembelajaran dengan baik. Selain itu dengan disusunnyaRPL akan memudahkan guru lain yang akan menggantikan guru tersebut pada kegiatan pembelajaran apabila guru tersebut berhalangan hadir. Oleh karena itu dalam penyusunan RPL harus jelas dan semua orang yang membacanya akan mengerti, di samping itu perlu dikalukan supervisi. Supervisi pembelajaran diselenggarakan dengan cara pemberian contoh, diskusi, pelatihan, dan konsultasi (Permendiknas No. 41/2007). Kegiatan supervisi yang dilakukan oleh pengawas satuan pendidikan dan pengawas sekolah adalah kegiatan untuk memperbaiki dan atau meningkkatkan. Hal yang diperbaiki atau ditingkatkan adalah perencanaan, pelaksanaan, dan penilaian proses pembelajaran. Cara yang digunakan adalah dengan pemberian contoh, disksusi, pelatihan, dan konsultasi. Pemilihan cara ini tentu sangat ditentukan oleh keadaan dan kebutuhan pendidik. Bisa jadi seorang pendidik hanya 
memerlukan contoh untuk meningkatkan kemampuan merencanakan, sedangkan pendidik yang memerlukan diskusi, konsultasi, dan pelatihan. Selain itu, kiat pengawas satuan pendidikan dan pengawas sekolah dalam mengemban tugasnya juga sangat berpengaruh terhadap pemilihan cara yang tepat.

Kegiatan supervisi tersebut dilaksanakan untuk peningkatan kemampuan guru dalam menyusun RPL sebagai salah satu upaya meningkatkan mutu pembelajaran sekaligus mutu pendidikan sekolah. Dalam supervisi klinis ini terdapat berbagai program atau pola pendekatan yang mampu meningkatkan dan mendorong guru untuk belajar, baik sikap, kemampuan, pengetahun maupun keterampilan sehingga memberikan dampak positif terhadap tugas pokok dan fungsinya sesuai tuntutan dan peraturan perundang-undangan yang berlaku. Dari uraian tersebut, penulis mengangkat judul : "Upaya Meningkatkan Kinerja Guru Bimbingan Konseling dalam Penyusunan Rencana Program Layanan melalui Pendampingan Supervisi Klinis di kelompok Kerja Delanggu Klaten Semester Gasal Tahun Pelajaran 2015/2016"

Permasalahan dalam penelitian ini, yaitu : Apakah melalui pendampingan supervisi klinis pengawas sekolah dapat mengoptimalkan unjuk kerja guru dalam penyusunan rencana program layanan (RPL) di kelompok kerja wilayah Delanggu Klaten semester genap tahun pelajaran 2015/2016? Sedangkan tujuan yang hendak dicapai yaitu tujuan umum adalah ingin mengetahui dan mengoptimalkan unjuk kerja guru dalam menjalankan tugas pokok dan fungsinya sebagai guru, dan tujuan khusus adalah ingin mengetahui dan mengoptimalkan pendampingan supervisi klinis pengawas sekolah terhadap unjuk kerja guru dalam penyusunan rencana program layanan (RPL) di kelompok kerja wilayah Delanggu Klaten semester genap tahun pelajaran 2015/2016

Manfaat yang diharapkan bagi guru, yaitu dapat dimanfaatkan guru dalam menyusun rencana program layanan (RPL), bagi peneliti, melalui pendampingan supervisi klinis yang dilakukan oleh pengawas sekolah dapat dimanfaatkan guru dalam menyusun rencana program layanan (RPL), dan melalui pendampingan supervisi klinis yang dilakukan oleh pengawas sekolah dapat dimanfatkan untuk meningkatkan mutu unjuk kerja guru dalam melaksanakan tugas pokok dan fungsinya, sehingga mampu mencapai tujuan sekolah dan pendidikan nasional. Sedangkan bagi sekolah dapat meningkatkan mutu kinerja guru bimbingan konseling dalam memberikan layanan kepada siswa dan masyarakat.

\section{METODE}

Penelitian tindakan sekolah ini berlangsung selama tiga bulan, dimulai tanggal 02 Agustus dengan 02 November 2015. Penelitian ini dilakukan di kelompok kerja wilayah Delanggu Klaten. Subjek penelitian adalah guru bimbingan konseling sebanyak 30 guru. Sumber data dalam penelitian ini adalah kolaborator, dan referensi dan atau sumber data tertulis sejenis. Teknik pengumpulan data menggunakan angket motivasi, observasi selama dan setelah dilaksanakan tindakan, observasi, wawancara, dan dokumentasi. Validitas data mengacu pada bukti dan fakta yang terjadi pada subjek yang diteliti berupa peningkatan atau perubahan sikap, pengetahuan, dan keterampilan yang lebih baik dalam menjalankan tugas pokok. Penelitian ini adalah penelitian tindakan kelas, jadi tidak perlu menggunakan analisis statistik untuk menguji validitas data. Teknik analisis data yang digunakan dalam penelitian ini adalah analisis kritis dan analisis komparatif. Teknik analisis kritis mengungkap kelemahan kelebihan subjek penelitian 
berdasarkan kriteria. Hasil analisis kritis dijadikan dasar penyusunan rancangan tindakan tahap berikutnya. Analisis kritis mencakup hasil menyelesaikan dalam mengembangkan rencana program layanan. sedangkan teknik komparatif adalah memadukan data penelitian deskripsi awal (prasiklus), siklus pertama, dan seterusnya. Hasil komparasi untuk mengetahui keberhasilan maupun kegagalan dalam setiap siklusnya.

Tindakan penelitian menggunakan model Kemmis dan Taggart, yaitu siklus sistem spiral, masing-masing siklus terdiri dari empat komponen, yaitu rencana, tindakan, observasi, dan refleksi (Suwandi, 2009). Indikator keberhasilan dari prasiklus dan seterusnya, bila sudah optimal, ada peningkatan partisipasi aktif dan perubahan sikap, pengetahuan, dan keterampilan, maka tindakan dihentikan. Intinya ada peningkatan hasil belajar peserta didik lebih baik sesuai kriteria ketuntasan minimal 80 dan ketuntasan kelas 100\%, dan prosedur penelitian ini dilakukan dengan menggunakan siklus.

\section{HASIL DAN PEMBAHASAN}

Kondisi awal, diperoleh data tentang kinerja guru bimbingan konseling dalam penyusunan dan pengembangan rencana program layanan (RPL) rata-rata sebesar 75 (tidak tercapai), nilai maksimal 84 (terlampaui), dan nilai minimal 67 (tidak tercapai). Jadi, ada 11 guru (37\%) yang sudah optimal dan sisanya belum optimal masih ada 19 guru (63\%), pada tahap kondisi awal ini hasil kinerja guru bimbingan konseling dalam penyusunan dan pengembangan RPL belum optimal, maka perlu ditindaklanuti siklus I. Hal ini, mendeskrikan kondisi nyata guru bahwa kinerja guru bimbingan konseling dalam penyusunan dan pengembangan rencana program layanan memang belum optimal, bahkan sebelum ada tindakan supervisi kepala sekolah, kinerja guru bimbingan konseling masih minimal, komunikasi dengan teman sejawat dan kepala sekolah masih terbatas pada komunikasi biasa, belum ada komunikasi secara khusus dan formal yang membahas tentang penyuusunan RPL yang ideal, artinya guru masih terbatas pada copy paste pada RPL yang memadai dan sesuai kondisi nyata layanan bimbingan konseling.

Tahap I, peneliti telah menetapkan atau menyusun rencana kegiatan berupa membuat instrumen penilaian kinerja guru bimbingan konseling, menyusun data penilaian kinerja guru bimbingan konseling dalam menyusun RPL, menentukan jadwal pertemuan, dan pelaksanaan supervisi klinis. Subjek peneliti supervis klinis kepada 30 guru bimbingan konseling yang telah ditetapkan dalam penelitian ini. Peneliti melaksanakan observasi yang didampingi kolaborator untuk mendapatkan data yang valid, misalnya berupa kegiatan mengamati kegiatan dan kerjasama guru dalam menyusun RPL. Hasil tindakan siklus I dapat diinformasikan sesuai kegiatan yang telah ditetapkan yang hasilnya dapat diosajikan secara tabulasi berikut ini.

Tahap siklus I, diperoleh data tentang kinerja guru bimbingan konseling dalam penyusunan dan pengembangan rencana program layanan (RPL) rata-rata sebesar 80 (tercapai), nilai maksimal 90 (terlampaui), dan nilai minimal 72 (tidak tercapai). Jadi, ada 22 guru (73\%) yang sudah optimal dan sisanya masih ada 8 guru (27\%), pada tahap siklus I ini hasil kinerja guru bimbingan konseling dalam penyusunan dan pengembangan RPL belum optimal, maka perlu ditindaklanuti siklus II.

Tahap II, peneliti menindaklanjuti tindakan siklus I telah menetapkan atau menyusun rencana kegiatan berupa membuat instrumen penilaian kinerja guru bimbingan konseling, menyusun data penilaian kinerja guru bimbingan konseling dalam menyusun RPL, menentukan 
jadwal pertemuan dan pelaksanaan supervisi klinis. Peneliti melaksanakan supervis klinis kepada lima guru yang telah ditetapkan dalam penelitian ini, lebih difokuskan pada pembinaan dan koreksi RPL sekaligus cara mengajar yang efektif. Peneliti melaksanakan obbservasi yang didampingi kolaborator untuk mendapatkan data yang valid, lebih menekankan masukanmasukan dari kolaborator dan faktual. Hasil tindakan siklus II sesuai kegiatan yang telah ditetapkan yang hasilnya dapat disajikan naratif berikut ini. Pada tahap siklus II, diperoleh data tentang kinerja guru bimbingan konseling dalam penyusunan dan pengembangan rencana program layanan (RPL) rata-rata sebesar 90 (terlampaui), nilai maksimal 98 (terlampaui), dan nilai minimal 87 (terlampaui). Jadi, ada 30 guru (100\%) sudah optimal dalam penyusunan dan pengembangan RPL.

Kondisi awal atau tahap kondisi awal, kondisi guru belum optimal dalam penyusunan Rencana Pelaksanaan Pembelajaean (RPL), masih copy paste RPL milik orang lain atau teman sejawat, atau bahkan terjadinya lesalahan kolektif yang dilakukan di MGMP sekolah, yaitu membuat dan menyediakan RPL yang dapat dogunakan secara umum di wilayah kabupaten tertentu, sehingga semua sekolah atau satuan kerja pendidikan formal memiliki RPL yang sama, baik sekolah bertaraf local, nasional maupun internasional. Siklus I, telah dilaksanaan supervisi klinis terhadap kinerja guru bimbingan konseling dalam menyusun RPL, tindakan yang dilakukan peneliti antara lain memberikan bimbingan perbaikan dalam menyusun RPL, mengembangkan RPL hingga pemetaan alokasi waktu pada guru , pada akhirnya ada peningkatan kinerja guru bimbingan konseling dalam menyusun RPL, namun hasilnya belum optimal, sehingga perlu dilanjutkan siklus II.

Selanjutnya, siklus II, dilaksanaan supervisi klinis terhadap kinerja guru bimbingan konseling dalam menyusun RPL, tindakan yang dilakukan peneliti antara lain memperhatyikan masukan-masukan dari kolaborator dan faktual, melakukan kporeksi dan perbaikan dalam menyusun RPL, sekaligus imp[lementasi dalam layanan bimbingan konseling yang efektif dan memberikan contoh-contoh layanan bimbingan konseling yang aktif, inovatif, kreatif, dan menyenangkan, juga masih perlunya mengembangkan RPL hingga pemetaan alokasi waktu, namun ada yang perlu dioptimalkan yaitu pada kolaborasi teman sejawat, dalam hal ini, guru saling bekerjasama dalam pemetaan SK dan KD, dilanjutkan pada mereview RPL dan silabus, memperbaiki RPL dan silabus, dan menyusun laporan lengkap RPL, dapat mencapai hasil yang optimal,artinya semua guru mampu menyusun RPL sesuai dengan pedoman yang terdapat dalam KTSP.

Peneliti, selanjutnya mengamati praktiknya pada kondisi awal guru masih belum optimal,karena antara RPL yang telah disusun dengan pelaksaannya masih ada kesenjangan, terutama pada indikator yang belum mampu disampaikan kepada peserta didik sesuai dengan alokasi waktu yang telah ditetapkan, juga pada metode dan pendekatan yang digunakan, dalam RPL belum dapat dilaksanakan secara utuh. Pada siklus I, guru sudah meningkat atau mulai optimal dalam pelaksanaan RPL, namun kendalanya pada RPL ada metode diskusi belum dapat dilaksanakan, karena guru masih mendominasi layanan bimbingan konseling. Dilanjutkan siklus II, guru sudah optimal dalam plaksanaan layanan bimbingan konseling, mampu melaksanakan RPL sesuai dengan pelaksanaannya dalam layanan bimbingan konseling.

Adanya kesinambungan atau keberlanjutan antara RPL dan pelaksanaan layanan bimbingan konseling pada observasi guru dalam supervisi, yang dapat disajikan tabulasi data dari kondisi 
awal, siklus I, dan siklus II serta pembahasan hasil supervisi guru tentang penyusunan rencana program layanan bimbingan konseling yang secara rinci dapat diuraikan berikut ini. Data yang diperoleh dari kondisi awal hingga siklus II, diperoleh rangkuman data kondisi awal, Siklus I, II kinerja guru bimbingan konseling dalam penyusunan rencana program layanan, pada kondisi awal rata-rata sebesar 75 dan siklus I rata-rata sebesar 80 serta siklus II rata-rata sebesar 90 . Dari data ini, tampak jelas bahwa terjadi kenaikan rata-rata nilai dari kondisi awal ke siklus I sebesar 5 digit (6,7\%), dari siklus I ke siklus II terjadi kenaikan sebesar 10 digit (12,5\%), dari pasiklus ke siklus II terjadi kenaikan sebesar 15 digit (20\%).

Nilai tertinggi tahap kondisi awal sebesar 84 dan siklus I sebesar 90 serta siklus II sebesar 98 Tampak jelas bahwa dari tahap kondisi awal ke siklus I terjadi dari kondisi awal ke siklus I sebesar 6 digit (7,1\%), dari siklus I ke siklus II terjadi kenaikan sebesar 8 digit $(8,9 \%)$, dan dari kondisi awal ke siklus II terjadi kenaikan sebesar 14 digit (16,7\%). Nilai terendah tahap kondisi awal diperoleh sebesar 67 dan siklus I sebesar 72 serta siklus II sebesar 87. dengan demikian, dapat ditegaskan bahwa dari tahap kondisi awal ke siklus I terjadi kenaikan sebesar 5 digit (7,5\%), dari siklus I ke siklus II terjadi kenaikan sebesar 15 digit (22,4\%), dan dari kondisi awal ke siklus II terjadi kenaikan sebesar 20 digit (29,9\%). Persentase kriteria kinerja guru bimbingan konseling dalam menyusun RPL mulai dari kondisi awal diperoleh sebesar $28 \%$ dan siklus I diperoleh sebesar 68\% serta siklus II sebesar 100\%. Tampak jelas bahwa dari tahap kondisi awal ke siklus I terjadi kenaikan sebesar 40\%, dari siklus I ke siklus II terjadi kenaikan sebesar 32\%, dan dari kondisi awal ke siklus II terjadi kenaikan sebesar $72 \%$. Dengan demikian, prestasi belajar siswa dalam layanan bimbingan konseling Biologi dari kondisi awal hingga siklus II terjadi kenaikan yang signifikan.

Dengan demikian, supervise klinis dapat memberikan manfaat bagi guru bimbingan konseling dalam melayani minat, bakat, motivasi, prestasi belajar, dan lain-lain, sebagaimana yang diungkapkan oleh Sukardi (2008:1), menyatakan bahwa supervisi klinis bagi guru bimbingan konseling berfungsi untuk menemukan bakat, minat, kecakapan dalam bidang studi, serta mendorong mereka agar suka dan mau meminta nasehat dan bimbingan kepada guru pada saat tertentu dimana mereka menghadapi permasalahan yang membutuhkan pemecahan yang cepat. Pelayanan bimbingan dan konseling memiliki peranan penting, baik bagi individu yang berada dalam lingkungan sekolah, rumah tangga (kelaurga), maupun masyarakat pada umumnya. salah satu misi dari bimbingan dan konseling adalah misi pengembangan, yaitu memfasilitasi perkembangan individu di dalam satuan pendidikan formal, dan non formal, keluarga, instansi, dunia usaha dan industri, serta kelembagaan masyarakat lainnya kearah perkembangan optimal melalui strategi upaya pengembangan individu, pengembangan lingkungan belajar, dan lingkungan lainnya, serta kondisi tertentu sesuai dengan dinamika perkembangan masyarakat

Keberadaan layanan bimbingan dan konseling dalam sistem pendidikan di Indonesia dijalani melalui proses yang panjang, sejak kurang lebih 40 tahun yang lalu. Selama perjalanannya telah mengalami beberapa kali pergantian istilah, semula disebut Bimbingan dan Penyuluhan (dalam Kurikulum 84 dan sebelumnya), kemudian pada Kurikulum 1994 dan Kurikulum 2004, 2006, dan 2013 berganti nama menjadi Bimbingan dan Konseling. Akhir-akhir ini para ahli mulai meluncurkan sebutan Profesi Konseling, meski secara formal istilah ini belum digunakan. Bimbingan dan konseling berttujuan untuk memperlancar dan 
mempermudah perkembangan dan pertumbuhan psikologi terhadap kematangan klienya secara sosial,untuk itu konselor haruslah memiliki kegairahan hidup punya keinginan menghibur orang lain.

Prinsip-prinsip yang berkenaan dengan program pelayanan Bimbingan dan Konseling; (a) bimbingan dan konseling bagian integral dari pendidikan dan pengembangan individu, sehingga program bimbingan dan konseling diselaraskan dengan program pendidikan dan pengembangan diri peserta didik; (b) program bimbingan dan konseling harus fleksibel dan disesuaikan dengan kebutuhan peserta didik maupun lingkungan; (c) program bimbingan dan konseling disusun dengan mempertimbangkan adanya tahap perkembangan individu; (d) program pelayanan bimbingan dan konseling perlu diadakan penilaian hasil layanan.

Prinsip-prinsip yang berkenaan dengan tujuan dan pelaksanaan pelayanan; (a) diarahkan untuk pengembangan individu yang akhirnya mampu secara mandiri membimbing diri sendiri; (b) pengambilan keputusan yang diambil oleh klien hendaknya atas kemauan diri sendiri; (c) permaslahan individu dilayani oleh tenaga ahli/profesional yang relevan dengan permasalahan individu; (d) perlu adanya kerja sama dengan personil sekolah dan orang tua dan bila perlu dengan pihak lain yang berkewenangan dengan permasalahan individu; dan (e) proses pelayanan bimbingan dan konseling melibatkan individu yang telah memperoleh hasil pengukuran dan penilaian layanan

Kegiatan layanan merupakan kegiatan dalam rangka memenuhi fungsi-fungsi bimbingan dan konseling. Sedangkan kegiatan pendukung merupakan kegiatan untuk menopang terhadap keberhasilan layanan yang diberikan. Dalam perspektif kebijakan pendidikan nasional saat ini terdapat tujuh jenis layanan dan lima kegiatan pendukung. Namun sangat mungkin ke depannya akan semakin berkembang, baik dalam jenis layanan maupun kegiatan pendukung. Para ahli bimbingan di Indonesia saat ini sudah mulai meluncurkan dua jenis layanan baru yaitu layanan konsultasi dan layanan mediasi. Namun, kedua jenis layanan ini belum dijadikan sebagai kebijakan formal dalam sistem pendidikan.

Adapun yang sudah formal dilaksanakan dalam dunia pendidikan sekolah, antara lain: Layanan Orientasi merupakan layanan yang memungkinan peserta didik memahami lingkungan baru, terutama lingkungan sekolah dan obyek-obyek yang dipelajari, untuk mempermudah dan memperlancar berperannya peserta didik di lingkungan yang baru itu, sekurang-kurangnya diberikan dua kali dalam satu tahun yaitu pada setiap awal semester. Tujuan layanan orientasi adalah agar peserta didik dapat beradaptasi dan menyesuaikan diri dengan lingkungan baru secara tepat dan memadai, yang berfungsi untuk pencegahan dan pemahaman.

Layanan Informasi; merupakan layanan yang memungkinan peserta didik menerima dan memahami berbagai informasi (seperti : informasi belajar, pergaulan, karier, pendidikan lanjutan). Tujuan layanan informasi adalah membantu peserta didik agar dapat mengambil keputusan secara tepat tentang sesuatu, dalam bidang pribadi, sosial, belajar maupun karier berdasarkan informasi yang diperolehnya yang memadai. Layanan informasi pun berfungsi untuk pencegahan dan pemahaman

Layanan Pembelajaran merupakan layanan yang memungkinan peserta didik mengembangkan sikap dan kebiasaan belajar yang baik dalam menguasai materi belajar atau penguasaan kompetensi yang cocok dengan kecepatan dan kemampuan dirinya serta 
berbagai aspek tujuan dan kegiatan belajar lainnya, dengan tujuan agar peserta didik dapat mengembangkan sikap dan kebiasaan belajar yang baik. Layanan pembelajaran berfungsi untuk pengembangan

Layanan Penempatan dan Penyaluran; merupakan layanan yang memungkinan peserta didik memperoleh penempatan dan penyaluran di dalam kelas, kelompok belajar, jurusan/ program studi, program latihan, magang, kegiatan ko/ekstra kurikuler, dengan tujuan agar peserta didik dapat mengembangkan segenap bakat, minat dan segenap potensi lainnya. Layanan Penempatan dan Penyaluran berfungsi untuk pengembangan.

Layanan Konseling Perorangan merupakan layanan yang memungkinan peserta didik mendapatkan layanan langsung tatap muka (secara perorangan) untuk mengentaskan permasalahan yang dihadapinya dan perkembangan dirinya. Tujuan layanan konseling perorangan adalah agar peserta didik dapat mengentaskan masalah yang dihadapinya. Layanan Konseling Perorangan berfungsi untuk pengentasan dan advokasi.

Layanan Bimbingan Kelompok merupakan layanan yang memungkinan sejumlah peserta didik secara bersama-sama melalui dinamika kelompok memperoleh bahan dan membahas pokok bahasan (topik) tertentu untuk menunjang pemahaman dan pengembangan kemampuan sosial, serta untuk pengambilan keputusan atau tindakan tertentu melalui dinamika kelompok, dengan tujuan agar peserta didik dapat memperoleh bahan dan membahas pokok bahasan (topik) tertentu untuk menunjang pemahaman dan pengembangan kemampuan sosial, serta untuk pengambilan keputusan atau tindakan tertentu melalui dinamika kelompok. Layanan Bimbingan Kelompok berfungsi untuk pemahaman dan pengembangan

Layanan Konseling Kelompok merupakan layanan yang memungkinan peserta didik (masing-masing anggota kelompok) memperoleh kesempatan untuk pembahasan dan pengentasan permasalahan pribadi melalui dinamika kelompok, dengan tujuan agar peserta didik dapat memperoleh kesempatan untuk pembahasan dan pengentasan permasalahan pribadi melalui dinamika kelompok. Layanan Konseling Kelompok berfungsi untuk pengentasan dan advokasi

\section{PENUTUP}

Hasil penelitian dan pembahasan tentang "Upaya Meningkatkan Kinerja Guru Bimbingan Konseling dalam Penyusunan Rencana Program Layanan melalui Pendampingan Supervisi Klinis di Kelompok Kerja Wilayah Delanggu Klaten Semester Gasal Tahun Pelajaran 2015/2016", dapat disimpulkan bahwa data kondisi awal, siklus I, II, kinerja guru bimbingan konseling dalam penyusunan rencana program layanan, pada kondisi awal rata-rata sebesar 75 dan siklus I rata-rata sebesar 80 serta siklus II rata-rata sebesar 90. Dari data ini, tampak jelas bahwa terjadi kenaikan rata-rata nilai dari kondisi awal ke siklus I sebesar 5 digit (6,7\%), dari siklus I ke siklus II terjadi kenaikan sebesar 10 digit (12,5\%), dari pasiklus ke siklus II terjadi kenaikan sebesar 15 digit (20\%).

Secara keseluruhan dapat ditegaskan bahwa proses pelaksanaan klinis dalam upaya meningkatkan kinerja guru bimbingan konseling menyusun RPL di kelompok kerja wilayah Delanggu Klaten semester gasal tahun pelajaran 2015/2016 memperhatikan beberapa hal, antara lain : kinerja masing-masing guru, batasan alokasi waktu, dilakukan secara terstruktur dan terpadu, menciptakan suasana akrab dengan pendidik, membahas perangkat rencana 
program layanan yang disusun dan dikembangkan guru guru bimbingan konseling sesuai dengan materi layanan, indikator layanan, tujuan layanan, penilaian, memperhatikan sumber belajar yang pendidik gunakan, memperhatikan perangkat alat, perangkat administrasi layanan bimbingan konseling seperti buku nilai siswa, produk belajar siswa, dan nilai akademik/.

Implikasi hasil penelitian, kemampuan guru dalam penyusunan RPL perlu terus ditingkatkan sesuai kondisi dan tuntutan perkembangan dan kemajuan pendidikan, terutama era global dan berbasis masyarakat, karena kemampuan tersebut akan menentukan keberhasilan guru dalam pelaksanaan kegiatan pembelajaran, dan akhirnya sampai pencapaian tujuan pendidikan nasional, misalnya mampu memberikan layanan kepada peserta didik mencapai puncak prestasi belajarnya. Selanjutnya, saran bagi guru, hendaknya meningkatkan kereativitas dan kemampuannya dalam penyusunan RPL, tidak copy paste, agar pelaksanaan pembelajarannya bermakna, karena memuat karakteristik sekolah, dan saran bagi peneliti lain, agar dapat mengembangkan penelitian sejenis, atau penelitian lain yang terkait dengan kemampuan guru, sehingga diperoleh temuan-temuan baru yang mampu memecahkan masalah-masalah di dunia pendidikan.

\section{DAFTAR PUSTAKA}

Budimansyah, Dasim, dkk, 2010. Pembelajaran Aktif, Kreatif, Efektif, dan Menyenangkan. Bandung: Genesindo.

Damayanti, Sri, 2008. "Profesionalisme Kepemimpinan Kepala Sekolah". http:// akhmadsudrajat.wordpress.com.

Karyono, Hary. 2005. Supervisi Untuk Meningkatkan Profesionalisme Guru di Sekolah Dasar (Study Multikasus di SD Laboratotoiim Sumber Ilmu, SD N Sekar Arum I, SDK Sang Surya dan SD Madukoro IV). Disertasi Program Pascasarjana Universitas Negeri Malang.

Mulyasa, E. 2009. Standar Kompetensi dan Sertifikasi Guru. Bandung: Remaja Rosda Karya. Mulyasa, E. 2010. Penelitian Tindakan Sekolah. Bandung: Remaja Rosda Karya.

Mulyasa, E. 2010. Kurikulum Tingkat Satuan Pendidikan. Bandung: Remaja Rosda Karya.

Muzayyin, Ma’mun. 2010. “Konsep Dasar Supervisi Pendidikan”. http://ajad-alhikmahkajen. blogspot.com

Peraturan Pemerintah Nomor 28 Tahun 1990, tentang Kepala Sekolah. Jakarta : Departemen Pendidikan dan Kebudayaan Republik Indonesia.

Sujati. 2000. Penelitian Tindakan Kelas. Yogyakarta :Universitas Negeri Yogyakarta.

Sulanam, 2010: 3. “Apa dan Mengapa Supervisi Klinis” http://www.sulanam. sunan-ampel. ac.id

Supandi. 2006. Administrasi dan Supervisi Pendidikan. Jakarta: Departemen Agama Universitas Terbuka

Supriyanto, 2006. Pola Pelaksanaan Supervisi Klini di Sekolah. Jakarta: Direktorat Pembinaan Pendidikan Dan Pelatihan PMPTK Depdiknas.

Suwandi, Sarwiji. 2009. Modul Pendidikan dan Latihan Profesi Guru : Penelitian Tindakan Kelas. Surakarta : UNS. 